\title{
PENERAPAN KONSELING EKSISTENSIAL HUMANISTIK PADA PASIEN SKIZOFRENIA TIDAK TERPERINCI (UNDIFFERENTIATED) DI RUMAH SAKIT JIWA MENUR SURABAYA
}

\section{Laksita Wulya Danastri, Tatik Meiyuntariningsih}

Universitas 17 Agustus 1945 Surabaya Jawa Timur, Indonesia

Email: queenlaksitawulya@gmail.com, tatikmeiyun@untag-sby.ac.id

\begin{abstract}
Abstrak
Skizofrenia merupakan suatu psikosa fungsional dengan gangguan utama proses pikir serta ketidak harmonisan antara proses pikir, emosi, kemauan, dan psikomotor disertai distorsi kenyataan terutama karena waham dan halusinasi, asosiasi terbagibagi sehingga muncul inkoherensi, emosi inadekuat, dan psikomotor menunjukkan penarikan diri, ambivalensi, dan perilaku bizar. Tujuan dari penelitian ini adalah untuk mengetahui cara kerja dan peran dari penerapan konseling eksistensial humanistik. Metode penelitian yang digunakan dalam penelitian ini menggunakan metode observasi dan wawancara dengan menggunakan pendekatan eksistensial humanistik. Hasil penelitian ini menunjukkan bahwa klien memiliki skor IQ sebesar 93 yang termasuk dalam kategori rata-rata. Hal tersebut mengindikasikan bahwa klien cukup mampu menyelesaikan tugas-tugas yang bersifat agak kompleks namun beberapa tugas masih membutuhkan bantuan orang lain. Klien memiliki indikasi MD sebesar $14,58 \%$. Terdapat kemunduran IQ akibat gangguan Skizofrenia yang dialami klien saat ini serta obat yang sudah dikonsumsi klien. Full IQ dan Original IQ klien hanya memiliki selisih 1 skor saja yang artinya klien memang memiliki kemunduran dan ada indikasi mengalami sakit atau gangguan.
\end{abstract}

Kata Kunci: skizofrenia; pasien; Rumah Sakit Jiwa

\section{Abstract}

Schizophrenia is a function psychosa with the main disorder of the process and the misaldity of harmony between thought processes, artistic, and psychomotor accompanied by ris hebata due to waham and hallucinations, divided associations so that there is an incoherence, artistic inadekuat, psychomotor self-showing, ambivalence and kris bizar. The purpose of this research is what exists to know the workings and roles of the style of mankind. Which research method in this study is observation and drawing method to close humanistic. The results of this study showed that the client scored an IQ score of 93 that was included in the Average team. As with the embankment, the client is quite capable so the tasks are a bit complex but some tasks are still syen help others. The client has an MD indication of $14.58 \%$. whether there is an IQ of schizophrenia disorder experienced by the client at this time and the medication that the client has Tidaken. Full IQ and Original IQ of the client is only a difference of 1 score which means the client does do the doing and there are indications of illness or disorder.

$\begin{array}{ll}\text { How to cite: } & \text { Danastri, Laksita Wulya dan Tatik Meiyuntariningsih (2021) Penerapan Konseling Eksistensial } \\ & \text { Humanistik pada Pasien Skizofrenia Tidak Terperinci (Undifferentiated). Syntax Literate: Jurnal } \\ & \text { Ilmiah Indoensia. 6(7). http://dx.doi.org/10.36418/syntax-literate.v6i7.3645 } \\ \text { E-ISSN: } & 2548-1398 \\ \text { Published by: } & \text { Ridwan Institute }\end{array}$


Keywords: schizophrenia; patients; Mental Hospital

\section{Pendahuluan}

Skizofrenia merupakan suatu psikosa fungsional dengan gangguan utama proses pikir serta ketidak harmonisan antara proses pikir, emosi, kemauan, dan psikomotor disertai distorsi kenyataan terutama karena waham dan halusinasi, asosiasi terbagi-bagi sehingga muncul inkoherensi, emosi inadekuat, dan psikomotor menunjukkan penarikan diri, ambivalensi dan perilaku bizar (Maramis \& Maramis, 2009).

Berdasarkan PPDGJ III, Skizofrenia ditandai oleh penyimpangan yang fundamental dan karakteristik dari pikiran dan persepsi, serta oleh afek yang tidak wajar (inappropriate) atau tumpul (blunted) (Ambarita, 2014). Kesadaran yang jernih (clear consciousness) dan kemampuan intelektual biasanya tetap terpelihara, walaupun kemunduran kognitif tertentu dapat berkembang kemudian (Hertinjung, Arifiani, \& Hanifah, 2020). Untuk mendiagnosis Skizofrenia harus ada sedikitnya satu gejala berikut ini:

1. Thought echo = isi pikiran dirinya sendiri yang bergema dan berulang dalam kepalanya dan isi pikiran yang berulang. Walaupun isinya sama namun kualitasnya beda Thought insertion or withdrawal = isi pikiran asing dari luar masuk ke dalam pikirannya (Insertion) atau isi pikirannya diambil keluar oleh sesuatu dari luar dirinya (Withdrawal) Thought broadcasting = isi pikirannya tersiar keluar sehingga orang lain mengetahuinya.

2. Delution of control = waham tentang dirinya dikendalikan oleh sesuatu kekuatan dari luar. Delution of influence = waham tentang dirinya dipengaruhi oleh sesuatu dari luar. Delution of perception = pengalaman inderawi yang tidak wajar yang bermaksa sangat khas bagi dirinya, biasanya bersifat mistik atau mukjizat. Delution of passivity = waham tentang dirinya tidak berdaya dan pasrah terhadap kekuatan dari luar.

3. Halusinasi auditorik adalah suara halusinasi yang berkomentar secara terus menerus tentang perilaku pasien (Pratami, 2013).

a. Suara halusinasi yang berkomentar secara terus menerus terhadap perilaku pasien.

b. Mendiskusikan perihal pasien diantara mereka sendiri.

c. Jenis suara halusinasi lain yang berasal dari salah satu bagian tubuh.

4. Waham-waham menetap jenis lainnya yang menurut budaya setempat dianggap tidak wajar dan sesuatu yang mustahil, misalnya perihal keyakinan agama atau politik tertentu atau kekuatan dan kemampuan diatas manusia biasa (mampu mengendalikan cuaca atau berkomunikasi dengan makhluk asing dari dunia lain.

5. Halusinasi yang menetap dari panca indera apa saja, apabila disertai baik oleh waham yang mengembang maupun yang setengah berbentuk tanpa kandungan afektif yang jelas ataupun disertai oleh ide-ide berlebihan (Over-valued ideas) yang menetap atau apabila terjadi setiap hari selama berminggu-minggu atau berbulan-bulan secara terus menerus (Ihsiani, 2019). 
6. Arus pikiran yang terputus (break) atau apa yang mengalami sisipan (interpolution), yang berakibat inkoherensi atau pembicaraan yang tidak relavan atau neologisme.

7. Perilaku katatonik, seperti keadaan gaduh-gelisah (excitement), posisi tubuh tertentu (posturing) atau fleksibilitas cerea, negativisme, multisme dan stupor.

8. Gejala-gejala "negatif" seperti sikap sangat apatis, bicara yang jarang dan respons emosional yang menumpul atau tidak wajar, biasanya yang mengakibatkan penarikan diri dari pergaulan sosial dan menurunnya kinerja sosial, tetapi juga harus jelas bahwa semua hal tersebut tidak disebabkan oleh depresi atau medikasi neuroleptika.

a. Adanya gelaja-gelaja khas tersebut diatas telah berlangsung selama kurun waktu satu bulan atau lebih (tidak berlaku untuk setiap fase nonpsikotik prodromal).

b. Harus ada suatu perubahan yang konsisten dan bermakna dalam mutu keseluruhan (overall quality) dari beberapa aspek perilaku pribadi (personal behavior), bermanifestasi sehingga hilanglah minat, hidup tidak bertujuan, tidak berbuat sesuatu, sikap larut dalam diri sendiri (self absorbed attitude), dan penarikan diri secara sosial.

Skizofrenia dibagi menjadi beberapa macam, yakni:

1. Skizofrenia Paranoid

Memiliki karakteristik yaitu kecurigaan yang ekstrim terhadap orang lain dengan halusinasi dan waham kejar atau waham kebesaran (Ripangga \& Damaiyanti, 2018).

2. Skizofrenia Hebefrenik

Ditandia dengan regiditas otot, negativisme, kegembiraan berlebihan atau posturing (mematung), ciri penyerta lain adalah gerak stereotip, manerisme, dan fleksibilitaslin (waxi flexibility), dan gejala yang sering dijumpai adalah mutisme (Fitriani, 2020).

3. Skizofrenia Katatonik

Ditandai dengan adanya percakapan dan perilaku yang kacau serta efek yang datar, gangguan asosial pasien, mempunyai sifat aneh, menunjukkan perilaku menarik diri secara sosial yang ekstrim, mengabaikan higine, penampil diri, dan terjadi sebelum usia 25 tahun (Enggar Ayuningtyas, 2020).

4. Skizofrenia Tidak Terperinci (Undifferentiated)

Gelaja yang muncul sulit digolongkan pada tipe Skizofrenia tertentu. Skizofrenia ini dikarakteristikkan dengan perilaku yang disorganisasi dan gejala-gejala psikosis yang mungkin memenuhi lebih dari satu tipe atau kelompok Skizofrenia. Skizofrenia tidak terperinci didiagnosis dengan memenuhi kriteria umum untuk diagnosa Skizofrenia, tidak memiliki kriteria untuk Skizofrenia paranoid, hiberfenik, katatonik, dan tidak memenuhi kriteria depresi pasca Skizofrenia.

5. Schizoaffective

Merujuk kepada perilaku yang berkarakteristik Skizofrenia, ada tambahan indikasi kelainan alam perasaan seperti depresi atau mania.

6. Skizofrenia Residual

Merupakan eksentrik tetapi gejala-gejala psikosis saat perilaku diperiksa atau dirawat tidak menonjol, menarik diri, dan efek serasi merupakan karakteristik dari 
kelainan ini adalah pasien yang memiliki riwayat paling sedikit satu episode Skizofrenia dan gejala-gejala yang menonjol (Rahmawati, 2019).

Kriteria diagnosis dalam Skizofrenia menurut (Maramis \& Maramis, 2009) meliputi:

1. Gangguan Isi Pikiran

Delusi atau kepercayaaan yang mendalam merupakan gangguan pikiran yang paling umum dihubungkan dengan Skizofrenia. Delusi ini mencakup delusi rujukan, penyiksaan kebesaran, cinta, kesalahan diri, kontrol, nihil atau doss, dan penghianatan. Delusi ini berkenaan dengan kepercayaan irasional mengenai suatu proses berpikir seperti percaya bahwa pikiran bisa disiarkan, dimasuki yang lain atau hilang dari alam pikirannya karena paksaan dari orang lain atau obyek dari luar. Delusi somatik meliputi kepercayaan yang salah dan aneh tentang kerja tubuh, misalnya pasien Skizofrenia menganggap bahwa otaknya sudah dimakan rayap (Sirait, 2012).

2. Gangguan dalam Bentuk Pikiran, Bahasa, dan Komunikasi

Proses berpikir dari pasien Skizofrenia dapat menjadi tidak terorganisasi dan tidak berfungsi kemampuan berpikir mereka menjadi kehilangan logika, cara mereka mengekspresikan dalam pikiran menjadi kehilangan logika, cara mereka mengekspresikan dalam pikiran dan bahasa dapat menjadi tidak dapat dimengerti, akan sangat membingungkan jika kita berkomunikasi dengan penderita gangguan pikiran (Sidqi, 2020). Contoh umum gangguan berpikir adalah inkoheren, kehilangan asosiasi, neologisme, blocking, dan pemakaian kata-kata yang salah.

3. Gangguan Persepsi Halusinasi

Salah satu simptom Skizofrenia yang merupakan kesalahan dalam persepsi yang melibatkan kelima alat indera kita walaupun halusinasi tidak begitu terikat pada stimulus yang di luar, tetapi kelihatan begitu nyata bagi pasien Skizofrenia. Halusinasi tidak berada dalam kontrol individu, tetapi begitu spontan walaupun individu mencoba untuk menghalangi (Hartanto, 2018).

4. Gangguan Afeksi (perasaan)

Pasien Skizofrenia selalu mengekspresikan emosinya secara subnormal dibandingkan dengan orang lain secara umum, perasaan ini konsisten dengan emosi tetapi reaksi ditampilkan tidak sesuai dengan perasaannya.

5. Gangguan Psikomotor

Pasien Skizofrenia kadang terlihat aneh dan dengan cara yang berantakan, memakai pakaian yang aneh atau membuat mimik yang aneh atau memperlihatkan gangguan katatonik stupor (keadaan dimana pasien tidak merespon stimulus dari luar atau tidak mengetahui ada orang disekitarnya), katatonik rigid (mempertahankan posisi tubuh atau tidak mengadakan gerakan) dan katatonik gerakan (selalu mengulang gerakan tubuh) menonjol adalah afek yang menumpul, hilangnya dorongan kehendak atau bertambahnya kemunduran sosial (Lawita, 2010).

Penelitian ini bertujuan untuk mengetahui cara kerja dan peran dari penerapan konseling eksistensial humanistik. 


\section{Metode Penelitian}

Metode yang digunakan dalam penelitian ini menggunakan metode observasi. Observasi merupakan salah satu metode pengumpulan data dengan cara mengamati atau meninjau secara cermat dan langsung di lokasi penelitian untuk mengetahui kondisi yang terjadi atau membuktikan kebenaran dari sebuah desain penelitian yang sedang dilakukan. Kegiatan observasi dilakukan untuk memproses objek dengan maksud untuk merasakan dan kemudian memahami pengetahuan dari sebuah fenomena berdasarkan pengetahuan dan ide-ide yang sudah diketahui sebelumnya, untuk mendapatkan informasi yang diperlukan dan melanjutkan ke proses investigasi (Sumantri, 2015).

Metode lain yang digunakan dalam penelitian ini adalah wawancara. Wawancara adalah suatu proses interaksi dan komunikasi. Dalam proses ini, hasil wawancara ditentukan oleh beberapa faktor yang berinteraksi dan mempengaruhi arus informasi. Faktor-faktor tersebut adalah pewawancara, responden, topik penelitian yang tertuang dalam daftar pertanyaan, dan situasi wawancara.

Penelitian diambil berdasarkan hasil rangkaian tes yang dilakukan oleh salah satu pasien di Rumah Sakit Jiwa Menur, Kota Surabaya, Jawa Timur. Pendekatan dalam penelitian ini adalah pendekatan eksistensial humanistik, pendekatan ini berfokus pada kondisi manusia, dimana menekankan pada pemahaman atas diri manusia itu sendiri. Tujuannya adalah membantu individu agar mampu bertindak, menerima kebebasan dan bertanggung jawab untuk tindakan yang dilakukan. Dalam terapi eksistensial berpijak pada premis bahwa manusia tidak bisa melarikan diri dari kebebasan, bahwa kebebasan dan tanggung jawab itu saling berkaitan. Dalam penerapannya pendekatan ini memusatkan perhatian pada kesadaran individu akan keberadaan dan potensi-potensi serta sadar bahwa ia dapat membuka diri dan bertindak berdasarkan kemampuannya (Corey, 2013).

\section{Hasil dan Pembahasan}

\section{A. Pelaksanaan Asesmen}

\section{Observasi}

\section{a. Observasi Fisik}

Secara umum klien memiliki penampilan yang bersih dan terawat. Klien memiliki tinggi $158 \mathrm{~cm}$ dengan berat badan $52 \mathrm{~kg}$. Berkulit kuning langsat dengan mata berwarna coklat gelap. Wajah klien bulat dan selalu menatap lawan bicaranya setiap kali berkomunikasi. Rambut klien pendek, sebelumnya sempat digundul saat pertama kali masuk Rumah Sakit Jiwa, bibir klien berwarna merah muda dan tidak tampak pucat, namun ketika berbicara air liur klien sering kali muncrat. Postur tubuh klien ideal namun agak pendek dibandingkan rata-rata laki-laki pada umumnya, cara berjalannya agak lemas, dan baju klien juga cenderung miring.

Klien lebih suka menyendiri dan menghabiskan waktunya hanya dengan duduk-duduk saja dengan tatapan mata yang kosong tanpa melakukan aktivitas lain sekalipun didekatnya ada pasien lain, klien hanya bicara ketika diajak bicara 
saja. Klien agak cadel sehingga beberapa kata yang diucapkan tidak terlalu jelas. Ketika bertemu dengan orang yang dikenalnya klien akan menyapa dengan melambaikan tangan, tersenyum, dan menyebut namanya.

\section{b. Observasi Lingkungan Rumah Sakit Jiwa}

Ruang perawatan klien berada di Bangsal Gelatik di Rumah Sakit Jiwa Menur tepat dibelakang Graha Menur. Bangunan ruangan cukup besar, bersih, dan terawat dengan baik. ditengah-tengan bangsal terdapat tumbuhan-tumbuhan dan beberapa pohon kecil yang membuat ruangan tampak teduh dan tidak terlalu panas. Dalam bangsal terdapat 2 ruangan untuk tidur yang sudah dilengkapi kamar mandi, dapur, ruang dokter, ruang isolasi, tempat makan, tempat rekreasi, tempat isolasi untuk pasien yang bermasalah, koperasi atau tempat yang menjual barang-barang yang diperlukan klien, serta tempat-tempat untuk bersantai atau untuk kunjungan keluarga klien. Dalam bangsal juga dilengkapi tempat khusus untuk pegawai Rumah sakit beserta tempat penyimpanan berkas rekam medis pasien.

Bangsal Gelatik merupakan bangsal untuk pasien kelas III sehingga pasien yang berada dalam ruang tersebut kebanyakan sudah koperatif dan dapat diajak berkomunikasi. Hampir tidak ada masalah yang ditimbulkan oleh pasien sehingga suasana dalam bangsal sangat tenang dan kondusif.

\section{c. Observasi Lingkungan Tempat Tinggal}

Tempat tinggal klien berada dalam lingkungan perumahan yang asri, klien termasuk dari golongan keluarga menengah keatas. Klien tinggal bersama ibu dan kedua saudaranya (kakak ke dua dan adiknya), selain itu dirumah juga ada kakak ipar serta keponakan klien yang masih berusia satu tahun. Rumah klien cukup besar dengan gaya Vintage sehingga masih banyak barang-barang dalam rumah yang antik dan unik. Di rumah klien terdapat empat kamar tidur dan beberapa diantaranya sudah dilengkapi dengan kamar mandi. Keluarga klien memiliki asisten rumah tangga untuk membantu membersihkan rumah dan memasak karena selama ini keluarga klien cenderung sibuk dengan pekerjaan masing-masing. Ibu klien sibuk mengurus cucunya, kakak pertama klien sedang dalam proses menyelesaikan studinya dan bekerja hingga malam, begitu juga dengan adik klien yang juga bekerja hingga pulang larut setiap hari. Lingkungan tempat tinggal klien bersih dan tenang, tetangga klien juga memahami kondisi klien dan sering kali membantu ibu klien ketika terjadi masalah terlebih jika masalah tersebut berhubungan dengan klien.

\section{Wawancara}

\section{a. Autoanamnesa}

Saat dilakukan wawancara dengan klien, klien menjelaskan dengan detail kejadian yang pernah klien alami maupun pengalaman yang sudah klien alami. Klien mampu menyebutkan nama lengkapnya dengan benar, namun saat menyebutkan tanggal lahir klien salah menuliskan tanggal lahirnya dan salah menuliskan alamatnya. Saat diminta tanda tangan klien menuliskan tanda 
tangannya dengan menggunakan simbol atau lambang kesukaan klien. Masa kecil klien suka dihabiskan dengan bermain bersama kakaknya karena usia kakaknya hanya berbanding 2 tahun saja dengan klien. Klien suka bermain sepak bola saat hujan dengan kakaknya saat berlibur di desa kelahiran ibunya. Klien juga suka bisa melihat persawahan yang hijau bersama kakaknya setiap kali berlibur ke desa.

Hubungan klien dengan orang tuanya cukup baik, klien berpendapat sebelum ayahnya meninggal klien merupakan anak kesayangan ayahnya, namun disisi lain juga merasa sangat berdosa pada ayahnya kerena pernah menyakiti ayahnya baik melalui kata-katanya ataupun pernah memukul ayahnya hingga kesakitan hanya karena masalah kecil, hingga saat beliau meninggal klien belum sempat minta maaf pada ayahnya atas kesalahannya saat itu. Pada saat ayahnya masih hidup dan belum pensiun, klien selalu tercukupi segala kebutuhannya dan berharap ayah klien mendapatkan promosi agar naik jabatan sehingga gaji ayahnya juga naik. Namun sayangnya saat itu ayah klien jatuh sakit dan harus beristirahat sehingga membuat keuangan keluarga klien menurun. Sosok ibu bagi klien adalah orang yang sangat penyayang dan selalu ada untuk klien. Ibu klien tidak pernah marah hanya saja agak kolot, cerewet dan terlalu over protective.

Klien tidak begitu dekat dengan saudaranya, kakak pertama klien sudah menikah dan tinggal di Tangerang sehingga komunikasi dengan kakaknya hanya melalui telfon, ketemu kakak secara langsung hanya pada saat lebaran saja. Hubungan klien dengan kakak keduanya cukup baik, kakaknya sering kali memberikan uang saku pada klien, namun klien benci pada kakaknya karena peristiwa sebelumnya dimana klien dipukul oleh kakaknya hingga nekat melaporkan kakaknya ke kantor Polisi. Hubungan klien dengan adiknya juga tidak begitu dekat, karena selama ini adiknya sangat sibuk dengan pekerjaannya, sehingga ketika pulang kerja malam dan terlihat lelah jadi jarang sekali berkomunikasi dengan klien. klien juga membenci adiknya karena bagi klien adiknya juga penyebab masuknya klien di Rumah Sakit Jiwa. Klien juga pernah tidak menyapa adiknya selama tiga minggu karena masalah kecil. Klien mengakui bahwa kakak dan adiknya sudah minta maaf padanya hanya saja klien merasa tidak bisa memaafkannya saat ini.

Setelah keluar dari rumah sakit jiwa klien berharap segera bekerja, keinginannya adalah bisa membeli salah satu jenis mobil mewah dalam waktu dekat ini. Namun klien tidak menyukai pekerjaan yang membutuhkan waktu lama dan harus ada tekanan, disisi lain klien mempunyai harapan tinggi bahwa klien bisa mendapatkan pekerjaan yang menggajinya banyak dalam sebulan tanpa lelah atau tertekan dalam bekerja. Klien tidak suka berbisnis karena dianggapnya terlalu ribet dan membutuhkan waktu lama untuk kaya.

Disisi lain klien sangat suka menceritakan pengalamannya saat kuliah terlebih saat menjelaskan mengenai pemograman yang pernah klien lakukan saat 
kuliah. Klien masih sangat ingat istilah-istilah yang ada didalam bahasa pemograman. Klien merasa senang ketika bercerita mengenai hal-hal yang di kuasainya atau dipahaminya dengan baik. klien berhenti kuliah karena merasa tertekan dengan tugas-tugas kuliahnya yang berat. Klien bisa menyelesaikan praktik hanya saja tidak suka jika harus ada ujian teori karena klien malas membaca atau menulis, bagi klien hal tersebut terlalu melelahkan dan lebih baik langsung dipraktikkan saja.

\section{b. Alloanamnesa}

Menurut keluarga klien merupakan anak yang sangat aktif, anak mama dan selalu cerita. Saat masih kecil tidak ada tanda-tanda gangguan pada klien sehingga klien tumbuh normal seperti anak pada umumnya. Klien mulai terlihat ada gangguan ketika sudah memasuki dunia perkuliahan, mulai berubah gaya hidup dan sikapnya. Klien suka menghambur-hamburkan uang dan mentraktir teman-temannya, klien juga selalu minta antar jemput orang tuanya dengan menggunakan mobil tidak mau jika harus naik angkot ataupun naik motor. Jika tidak diberikan uang klien akan marah dan pernah melempar barang pada ibunya. Ketika ayahnya meninggal ibunya berjualan pecel dengan menggunakan mobilnya untuk mencukupi kebutuhan keluarga, saat itu juga adik klien juga dalam proses menyelesaikan kuliahnya.

Beberapa kali dirumah klien terlibat perbedaan pendapat dengan kedua saudaranya namun kedua saudaranya selalu memilih mengalah agar masalah tidak tambah besar dan membuat klien emosi. Klien sangat sensitif sehingga mudah tersinggung dan tidak dapat ditekan, klien juga jarang sekali mengungkapkan perasaannya pada keluarganya sehingga keluarga tidak tahu apa yang sebenarnya klien rasakan. Klien memilih untuk memendamnya dan mengurung dirinya dalam kamar seharian penuh. Klien juga sering kali usil menggoda adiknya dengan selalu membuang air yang akan dipakai adiknya mencuci atau untuk mandi, saat ditanya alasannya klien mengatakan bahwa airnya sudah kotor dan harus diganti.

Menurut ibunya keadaan rumah berubah menjadi tegang setiap kali klien marah dan bertengkar dengan saudaranya. Ibunya merasa bahwa klien menganggap ibunya tidak peduli dan cenderung membeda-bedakan anak. Klien pernah berkata bahwa selama ini ibunya selalu membela kakak dan adiknya sehingga klien selalu dalam posisi terpojokkan. Hal tersebut membuat ibu klien ingin segera menikahkan klien, ibu klien beranggapan bahwa dengan menikah klien akan belajar bertanggung jawab dengan keluarganya, ibu klien pun mengatakan sanggup membiayai seluruh kebutuhan klien beserta istrinya serta dibantu untuk memulai bisnis agar dapat dijalankan bersama untuk bekal kehidupannya klien nantinya.

\section{Tes Psikologi}

Berdasarkan penelitian, untuk mengungkap gangguan skizophrenia yang dialami klien, maka digunakanlah alat tes sebagai berikut untuk mengungkap nilai 
IQ serta gambaran mengenai diri klien termasuk id, ego superego yang membentuk klien hingga saat ini dan figur dalam keluarga. Alat tes yang digunakan adalah:

a. Tes DAP

Klien cenderung menarik diri dari lingkungan sosialnya, klien lebih suka menghabiskan waktu sendirian dengan memikirkan beberapa hal yang akan dilakukannya setelah itu. Klien kurang percaya diri dan merasa tidak yakin akan kemampuannya sendiri, hal tersebut membuat klien kurang bersemangat dalam aktivitas sehari-harinya. Ada rasa tertekan dalam diri klien sehingga klien cenderung menghindari masalah dan memilih meninggalkan masalah tersebut daripada menyelesaikannya.

Klien belum dapat menerima kenyataan atas keadaanya saat ini, selalu merasa tidak aman dan lemah sehingga cenderung membutuhkan dorongan dari lingkungan sekitarnya. Disisi lain juga klien memiliki perasaan berdosa akan masa lalunya dan memiliki keinginan untuk memperbaikinya namun dalam dirinya merasa ada keraguan untuk memulai.

b. Tes BAUM

Imajinasi klien cukup besar sehingga klien suka berfantasi mengenai kehidupannya kedepan, termasuk individu yang idealis, memiliki hasrat yang tinggi untuk sukses namun ada rasa takut untuk memulai. Klien cenderung individualis dan mudah meremehkan orang lain. Disisi lain klien seringkali merasa tertekan sehingga mudah sekali emosi jika keadaan tidak sesuai dengan keinginannnya. Klien kurang dapat membuat keputusan yang tepat dan cenderung tergesa-gesa dalam menangkap pengertian akan sesuatu.

Disisi lain klien ada keinginan untuk dapat bergaul dengan banyak orang, klien juga merupakan pribadi yang menyenangkan hanya saja beberapa hal membuat klien tampak sombong dan terlalu membanggakan kemampuannya. Setelah membanggakan dirinya sendiri, kepercayaan diri klien akan muncul sedikit demi sedikit.

c. Tes HTP

Hubungan klien dengan orang tuanya tidak begitu baik, karena bagi klien baik ibu atau ayah merupakan sosok yang kurang dalam melakukan perannya sebagai orang tua pada klien. Hal tersebut membuat klien memiliki keinginan untuk keluar dari lingkungan keluarga karena selama ini klien menganggap bahwa dirinya kurang berperan dalam keluarga dan merasa adanya penolakan dari keluarga, sehingga klien lebih suka mencari penghiburan dirinya diluar rumah.

\section{d. Tes SSCT}

Klien memiliki ketakutan yang berlebihan mengenai kegagalan di masa depannya, rasa tersebut muncul akibat rasa bersalah klien terhadap apa yang telah klien lakukan dulu sehingga klien memiliki banyak kekhawatiran mengenai cita-citanya yang belum tercapai. Disamping itu tidak adanya pengalaman klien dalam berhubungan dengan wanita membuat klien merasa 
malas, bagi klien wanita hanya mau dengan orang yang punya uang saja sedangkan klien sendiri belum dapat menghasilkan uang sendiri. Hal tersebut yang dijadikan klien alasan mengapa hingga saat ini klien memutuskan untuk sendiri dulu.

e. Tes TAT

Klien memiliki rasa ingin tahu yang tinggi, sehingga klien selalu mencoba belajar dari orang-orang terdekatnya tentang suatu hal yang menarik baginya. Namun disisi lain klien merasa lelah dengan kehidupannya saat ini, merasa bahwa tidak ada orang yang memberikannya dukungan serta mau mendengarkan klien disaat klien merasa sedih atau binggung. Klien merasa dirinya membutuhkan perlindungan dan lebih banyak kasih sayang dari orang lain, karena bagi klien saat ini beberapa orang mencoba menyakiti klien dan tidak dapat memahami keinginan klien. Hal tersebut membuat klien merasa membutuhkan tempat dimana klien bisa merasakan kebebasan, ketenangan, dan menyenangkan.

f. Tes WWQ

Klien mengalami beberapa kecenderungan, diantaranya adalah klien mengalami Depressive and Hypochendriace Tendenzen yang artinya klien merupakan individu yang pesimis dalam mencapai tujuannya, klien juga memiliki emosi yang sensitif sehingga mudah marah jika dihadapkan pada situasi yang tidak sesuai baginya, adanya rasa bersalah membuat klien mudah cemas walau dengan hal yang bersifat sepele. Klien merasa tidak bahagia dengan hidupnya, sehingga gangguang tersebut juga menyerang pada fisik klien. Seperti klien mudah sekali mengeluhkan sakit pada tubuhnya, disisi lain hal itu juga membuat klien kesulitan untuk tidur dan berkonsentrasi.

Selain itu klien juga mengalami Pshisoide Tendenzen yakni tidak adanya keinginan klien untuk berhubugan dengan orang lain, klien cenderung menghindar dan menarik diri ketika berada dilingkungan sosial. Disamping itu juga klien memiliki Tendenzen zur Haltlusigkeit (instabillitie) yakni kondisi dimana klien memiliki suasana hati dan emosi mudah sekali berubah-ubah (tidak stabil).

g. Tes SCL 90

Klien mengalami kecemasan, hanya saja kecemasan tersebut sudah menunjukkan penurunan, perlahan kecemasan pada diri klien sudah dapat teratasi dengan baik.

h. Tes WAIS

Klien memiliki kapasitas intelektual dengan skor 93 yang berada dalam kategori Rata-Rata, artinya klien mampu menyelesaikan persoalan yang agak kompleks namun dalam beberapa hal masih membutuhkan bantuan orang lain. pada original IQ klien memiliki skor yakni 94 dan juga dalam kategori rata-rata, hanya memiliki selisih satu skor saja dengan full IQ klien. Namun klien memiliki 
indikasi penurunan MD sebesar 14,58 \%, hal ini didapatkan akibat gangguan Skizofrenia yang dialaminya serta obat yang dikonsumsi klien.

Verbal IQ bertanda diatas performance IQ mengindikasikan klien tidak mampu mengaplikasikan hal-hal yang ada dalam pikirannya. Klien memiliki konsentrasi yang kurang sehingga mudah teralihkan, disatu sisi klien kurang dalam pekerjaan yang berhubungan dengan angka dan hitungan serta kurang dalam mengingat peristiwa atau hal yang termasuk dalam ingatan jangka pendek.

Klien memiliki pembentukan konsep yang baik, sehingga mampu berpikir secara abstrak dan dapat menelaah masalah secara praktis. Kemampuan penggunaan bahasa yang dimiliki klien juga baik, membuat klien memiliki ide, wawasan, serta pengalaman yang cukup banyak. Dalam hal ini kemampuan klien dalam ingatan jangka panjang ataupun pembentukan konsep juga baik sehingga klien tidak mengalami kesulitan dalam memahami persoalan umum.

\section{Dinamika Psikologi}

Beberapa asesmen yang telah dilakukan, maka diketahui bahwa klien memiliki skor IQ sebesar 93 yang termasuk dalam kategori Rata-rata. Hal tersebut mengindikasikan bahwa klien cukup mampu menyelsaikan tugas-tugas yang bersifat agak kompleks namun beberapa tugas masih membutuhkan bantuan orang lain. Klien memiliki indikasi MD sebesar 14,58\%, terdapat kemunduran IQ akibat gangguan Skizofrenia yang dialami klien saat ini serta obat yang sudah dikonsumsi klien. Full IQ dan Original IQ klien hanya memiliki selisih 1 skor saja yang artinya klien memang memiliki kemunduran dan ada indikasi mengalami sakit atau gangguan.

Secara emosional klien mengalami ketidakstabilan, klien merasa rendah diri dan memiliki beberapa kecemasan. Banyak hal sepele yang membuat klien tertekan terlebih jika hal tersebut tidak menguntungkan atau tidak sesuai dengan apa yang diharapkan klien. Kondisi ini membuat klien merasa tidak nyaman, namun binggung harus melakukan apa. Dalam hal ini klien membutuhkan banyak perhatian dan dukungan dari keluarga maupun lingkungan tempat tinggalnya. Disisi lain klien juga mudah marah, hal ini membuat klien bersifat agresif dan tidak dapat dikendalikan saat marah.

Hubungan klien dengan keluarga cukup baik, hanya saja klien sering kali memiliki persepsi yang berbeda mengenai keluarganya, klien juga sangat ketergantungan pada ibunya. Bagi klien ibu adalah orang yang berjuang membesarkannya dan selalu menyayangi klien. Namun selama ini klien masih belum pernah menunjukkan rasa sayang dan terimkasih pada ibunya karena malu jika ibunya tidak merespon seperti yang diinginkannya. Meskipun hubungan klien dengan keluarga cukup baik, klien hampir tidak pernah menceritakan masalah yang di hadapinya kepada keluarga, klien memilih memendam masalah tersebut dan merasa bahwa jika diceritakan keluarganya juga tidak akan pernah memahaminya.

Secara sosial, klien cenderung menghindar. Klien tidak mudah bergaul dengan orang lain, ada rasa malu dan takut untuk memulai. Hal tersebut muncul karena klien 
tidak cukup percaya diri untuk menjalin hubungan sosial dengan lingkungan sekitarnya. Ini membuat klien tidak memiliki teman untuk bercerita dan berbagi serta cenderung menghabiskan waktunya sendiri, kurang adanya semangat untuk beraktivitas dan tajut melakukan hal baru karena merasa hal tersebut pasti akan memberikan tekanan pada klien, klien bukan individu yang dapat tahan dengan tekanan sehingga lebih memilih berdiam diri dan berpikir rencana kedepannya. Sikap keras yang suka menyendiri tersebut menunjukkan adanya hambatan klien dalam menempatkan diri dalam lingkungan sekitarnya, adanya gangguan dalam menyesuaikan diri serta dalam hubungan dengan realitas.

\section{Kesimpulan}

Kesimpulan yang didapat dari penelitian ini menunjukkan bahwa proses intervensi terhadap klien berjalan cukup lancar karena adanya kerja sama yang baik antara praktikan, keluarga, dan klien. Berdasarkan penelitian dengan menerapkan konseling eksistensial humanistik pada pasien Skizofrenia, sebelumnya klien cenderung menyalahkan dirinya mengenai kegagalan yang dialami selama ini, merasa kurang yakin terhadap dirinya sendiri, mudah tertekan dan merasa semua orang tidak mengerti dirinya, klien tidak mau meminta maaf pada ibunya mengenai kesalahannya yang dilakukan sebelum masuk RSJ, hubungan klien dengan saudaranya buruk, klien tidak mau menerima maaf dari saudaranya ataupun menerima maaf saudaranya, menghabiskan waktunya untuk melamun dan mengurung diri di kamar, tidak realistik dalam memilih pekerjaan, gaji, dan keinginan untuk membeli beberapa barang bermerk. Setelah penerapan konseling eksistensial humanistik pada pasien Skizofrenia klien mulai mengakui kelemahan dan juga potensi apa yang dimiliki, klien mau belajar lagi untuk mengatasi kelemahannya, mulai dapat mengatur emosi dan mau bercerita ketika sedang bingung, mulai terbuka mengenai pikiran yang tidak dapat diselesaikan kepada ibunya, klien mau meminta maaf kepada ibunya serta kesaudaranya atas kesalahannya, klien juga mengatakan hal yang selama ini belum pernah dikatakan klien pada ibunya karena malu, klien mengatakan sayang kepada ibunya, meminta maaf karena sudah banyak merepotkan ibunya serta berterimakasih atas perjuangan ibunya selama ini, hubungan klien dengan saudaranya mulai membaik, mau menerima maaf saudaranya dan meminta maaf. Klien dan saudaranya selalu menghabiskan waktu bersama ketika sebelum tidur, berbincang mengenai kegiatan apa saja yang klien lakukan di rumah setiap hari, klien mulai menghabiskan banyak waktunya dengan membantu dirumah seperti bersih-bersih, berbelanja, mencuci piring, dan lain-lain, klien juga tidak melamun lagi karena ketika bosan klien memilih untuk menonton tv ataupun mendengarkan siaran radio, klien mulai mencari pekerjaan yang sesuai dengan kemampuan yang klien miliki, klien juga tidak terlalu muluk dalam menetapkan standar gaji dan barang apa saja yang akan dibeli dalam waktu dekat, klien ingin menabung terlebih dulu dan tidak menghamburkan uang untuk hal yang tidak perlu karena uang didapatnya susah. 


\section{BIBLIOGRAFI}

Ambarita, Roi Holan. (2014). Skizofrenia Paranoid Pada Wanita Usia 38 Tahun. Jurnal Medula, 2(03), 101-110. Google Scholar

Corey, Gerald. (2013). Teori Praktek Konseling dan Psikoterapi. Bandung: Refika Aditama. Google Scholar

Enggar Ayuningtyas, Palupi. (2020). Studiliteratur: Asuhan Keperawatan Pada Pasien Skizofrenia Dengan Masalah Keperawatan Isolasi Sosial Menarik Diri. Universitas Muhammadiyah Ponorogo. Google Scholar

Fitriani, Anisa. (2020). Psikoterapi Suportif pada Penderita Skizofrenia Hebefrenik. Proyeksi: Jurnal Psikologi, 13(2), 123-133. Google Scholar

Hartanto, Agung Eko. (2018). Model Peran Keluarga Dalam Perawatan Diri Pasien Skizofrenia. Universitas Airlangga. Google Scholar

Hertinjung, Wisnu Sri, Arifiani, Desti, \& Hanifah, Monica Huaida. (2020). Terapi Okupasi untuk Meningkatkan Kesabaran pada Pasien RSJD. Proceeding of The URECOL, 68-72. Google Scholar

Ihsiani, Nadhifa. (2019). Hubungan antara Derajat Merokok dengan Fungsi Kognitif Penderita Skizofrenia. Universitas Andalas. Google Scholar

Lawita, Yola. (2010). Investarisasi gejala-gejala gangguan psikomotorik sebagai indikator autisme anak. Universitas Negeri Malang. Google Scholar

Maramis, Willy F., \& Maramis, Albert A. (2009). Catatan ilmu kedokteran jiwa edisi 2. airlangga university Press. Google Scholar

Pratami, Yusi Nurlianti. (2013). Skizofrenia Paranoid Pada Seorang Wanita Dengan Faktor Psikososial Sebagai Stressor. Jurnal Medula, 1(04), 117-122. Google Scholar

Rahmawati, Ety Diah. (2019). Asuhan Keperawatan Pada Pasien Skizofrenia Residual Dengan Masalah Harga Diri Rendah Kronik Di Rumah Sakit Jiwa Daerah Dr. Arif Zainudin Surakarta. Universitas Muhammadiyah Ponorogo. Google Scholar

Ripangga, Fanggi, \& Damaiyanti, Mukhripah. (2018). Hubungan Beban Keluarga Dengan Sikap Keluarga Dalam Merawat Pasien Skizofrenia Di Poliklinik Rumah Sakit Jiwa Atma Husada Mahakam Samarinda. Google Scholar

Sidqi, Inayah. (2020). Ruqyah Surat al-Zalzalah Sebagai Upaya Penanganan Pasien Penderita Skizofrenia di Yayasan Jalma Sehat Pusat Rehabilitasi dan Cacat Mental Bulungkulon Jekulo Kudus. IAIN Kudus. Google Scholar

Sirait, Deskina. (2012). Pendekatan Terapi Spiritual terhadap Penderita Skizofrenia. 
Laksita Wulya Danastri, Tatik Meiyuntariningsih

Google Scholar

Sumantri, H. (2015). Metodologi penelitian kesehatan. Prenada Media. Google Scholar

\section{Copyright holder:}

Laksita Wulya Danastri, Tatik Meiyuntariningsih (2021)

First publication right:

Syntax Literate: Jurnal Ilmiah Indonesia

This article is licensed under:

(c) (i) (?) 